\title{
Exploring the Influence of Commodity Prices, Real Exchange Rate and Trade Openness on Economic Performance in an Emerging Country
}

\author{
Ipeleng Ntshwe ${ }^{1} \&$ Rufaro Garidzirai ${ }^{2}$ \\ ${ }^{1}$ Department of Mineral Resources and Energy, Pretoria, South Africa \\ ${ }^{2}$ Department of Management, Walter Sisulu University, Butterworth, South Africa \\ Correspondence: Rufaro Garidzirai, Department of Management, Walter Sisulu University, Butterworth, South Africa. \\ E-mail: garidzirairufaro@gmail.com
}

Received: January 13, 2021

Accepted: February 17, 2021

Online Published: August 16, 2021

doi:10.5430/ijfr.v12n5p80

URL: https://doi.org/10.5430/ijfr.v12n5p80

\begin{abstract}
Do commodity prices, real exchange rate and trade openness influence economic growth in South Africa? This question is fundamental to academic research since it forms the basis of macroeconomic policies. Therefore, the comprehension of such a relationship is vital which has ushered this study into investigating the effect of real exchange rate, commodity prices and trade openness on economic growth in South Africa from 1984-2019. The purpose of this study is to contribute to the diverse literature on macroeconomics and international trade in the continent and the rest of the world. To achieve this, the Johansen cointegration method and Vector Error Correction Model were employed. The Johansen cointegration method confirmed the existence of a long-run relationship among the variables. Commodity prices and trade openness positively influenced economic growth while real exchange rate inversely influenced economic growth. The Vector Error Correction Model also confirmed that the disequilibrium in the model can be corrected in 1 year 9 months. The study`s findings suggest a methodical monetary policy synthesis that controls both the commodity price stability and exchange rate that spurs economic growth.
\end{abstract}

Keywords: commodity prices, economic growth, exchange, South Africa, trade openness, Vector Error Correction Model

\section{Introduction}

Recently, a majority of the countries worldwide have experienced economic instability due to the COVID-19 pandemic. Regrettably, the pandemic has crippled the economy of many emerging countries, South Africa included. The negative economic growth of -2.4 percent from 0.15 percent in 2020 attests to such claim (Trading Economics 2020). Economists further predict another decline in the country's economic growth to -5.8 percent by mid-2021 (Statista 2020). Such economic decline has far reaching consequences. This calls for policy makers to devise appropriate macroeconomic policies to solve the compromised economic growth. Thus, the current researchers opine that commodity prices, trade openness and commodity prices play a crucial role in resuscitating South Africa`s economy. Of importance is that the relationship among commodity prices, trade openness and exchange rate and economic growth is intertwined and cannot be overemphasised.

The macroeconomic proponents share the notion that trade openness increases the economies integration through export and importation of goods and services (Dao 2014, Gries \& Redlin 2012). The proponents maintain that trade openness improves economic growth, provided the host country's inflation rate is significantly low. Moreover, Mputu (2016) posits that a combination of trade openness and stable commodity prices are a catalyst for economic development. The rationale is that stable commodity prices guarantee income from importers that in turn increase production and economic growth. Contrariwise, commodity price instability inversely influences economic growth. Furthermore, the influence of real exchange rate is twofold. On one side, a higher exchange rate makes exports more expensive and reduces the demand of local goods and services (Rodrik 2008). Instead, a lower exchange rate tends to make exports attractive which increase the demand of local goods and services that eventually increases economic growth. Though a lower exchange rate is desirable, it has a tendency of causing inflation if it is not managed. Therefore, an appropriate synthesis should be applied to achieve economic growth. 
The absence of significant evidence to support the use of both devaluated or overvalued exchange rate in determining commodity prices and trade openness has elicited endless debates on how these influence economic growth. At the core of this debate was the appropriateness of using the floating exchange rate policy that appears to bring currency instability. Miyajima (2019) avers that the floating exchange rate has caused commodity price volatility in South Africa which also has a negative effect on the trade. From 2000 up to date, South Africa`s monetary authorities have implemented the flexible exchange rate policy (Muzekenyi et al. 2018). Flexible exchange rate is the exchange rate policy which is set by market forces (Muzhani 2018). The flexible exchange rate policy proponents contend that the policy automatically adjusts to external shocks, brings price stability and promotes financial sector stability (Habib et al. 2016). On the other hand, the flexible exchange rate policy antagonists postulate that the policy causes commodity prices to be intrinsically volatile and jeopardises the risk that could have been managed by both importers and exporters (Muzekenyi et al. 2016).

Given the perceived substantial economic contribution of commodity prices, trade openness and real exchange on economic growth, it is crucial to investigate the effects of the aforementioned variables on economic growth. The main objective is to evaluate the role of commodity prices, trade openness and real exchange on economic growth. The study was motivated by the fact that the exchange rate has been fluctuating, thereby influencing commodity prices to fluctuate as well. Thus, the researchers investigated the effect of the aforementioned variables on economic growth. Furthermore, contemporary studies have bewailed the lack of studies into this relationship (Muzekenyi et al. 2019, Brixiova \& Ncube 2014, Nyathi 2017). Studies on these issues relationship have been criticized for being infrequent and inadequate since they form the basis of macroeconomics and international economics. According to the researchers knowledge, there is no study that has interrogated the effects of commodity prices, trade openness and real exchange rate on South Africa's economy. Thus, this study has covered this research lacuna by investigating the effects of commodity prices, trade openness and real exchange rate on economic growth in South Africa.

\section{Literature Review}

Economic analysts have propounded that real exchange rate, commodity prices and trade openness have a crucial role on economic performance. For instance, policy makers prefer the devaluation of the exchange rate since it makes local goods and services relatively cheaper compared to that of a trading partner (Ojuolape et al. 2015). This increases the number of goods exported and leads to an escalation in the demand for goods and services produced in a country (Zhanje \& Garidzirai 2018). The increase in the demand and exports of goods generates an increase in the production of goods and services that eventually increases the number of goods and services produced in a country. On the other hand, a devalued exchange rate invokes inflation especially in the long-run (Pasara \& Garidzirai 2020). This follows the notion that an increase in the demand of goods and services leads to an increase in the price of goods and services. An increase in the price of goods and services will also lead to an increase in the prices of imports relative to exports.

Supposing that the prices of both imports and exports are elastic, the devaluation of exchange rate will positively influence trade openness and ultimately improve economic growth. However, Keho and Wang (2017) argued that trade openness contributes to economic growth if the inflation rate in that country is low and stable. In this case South Africa`s inflation rate (4.6\%) is considerably stable and low (Statistics South Africa 2020). Furthermore, commodity prices are important in emerging countries as they form part of significant exports and economic building. In South Africa, the most important exported commodities are raw materials such as mineral products and agricultural products (Trading Economics 2020). Economic growth is likely to increase when commodity prices are stable, while commodity price instabilities distort economic growth (Djordjevic 2019).

The relationship among these variables are twofold: complimentary and substitutability. The complimentary view states that commodity prices, trade openness and real exchange rate positively influence economic performance (Muzekenyi et al. 2018: Veira et al. 2013). Contrawise, the substitutability view shares the notion that commodity prices, trade openness and real exchange rate negatively influence economic performance (Nyathi 2017: Brixiova \& Ncube 2014). A study conducted in the past two decades, revealed that real exchange rate is the macroeconomic instrument that promotes economic growth (Acar 2000). The author maintained that a depreciation in the real exchange rate increases economic growth through the manufacturing multiplier effect. Razzaque et al (2017) and Khomo et al (2020) concur and further state that a depreciation in the local currency boosts exports and eventually promotes economic growth. Furthermore, Habib et al. (2016) found that real exchange rate, whether it be devaluation or appreciation, positively influences economic growth. Contrary, Ehigiamusoe and Lean (2019) argued that real exchange rate has an inverse relationship on economic growth. The authors maintained that real exchange rate brings the volatility element that hampers economic growth. 
Nyathi (2017), Brixiova and Ncube (2014) and Cavalcanti (2011) unearthed a bidirectional association between commodity prices and economic growth. For instance, Nyathi (2017) employed the Dynamic Ordinary Least Squares and granger causality methodologies to investigate the relationship between energy prices and economic growth in South Africa. The author found that commodity prices and economic growth granger cause each other. Similar results were found by Brixiova and Ncube (2014). A recent study by Ofori-Abebresse et al (2017) investigated the impact of commodity prices and exchange rate on economic growth in Ghana and Ivory Coast using the ARDL model. The authors used commodity price as a proxy of cocoa and found that higher cocoa prices reduce economic growth. Muzekenyi et al (2018) shares the same sentiments that commodity price instability distorts economic growth both in the short-run and long-run. The authors reached this decision after employing the Vector Error Correction Model (VECM).

Jawaid (2014) investigated the association between trade openness and economic growth in Pakistan. The study utilised the ARDL and concluded that trade openness has a positive effect on economic growth. The granger causality methodology further confirmed the trade openness and economic growth union. Using the same methodology, Malefane and Odhiambo (2018) found that trade openness positively contributes to economic growth in South Africa. Mizan (2019) carried out a panel study examining the influence of trade openness on economic growth and found that trade openness does not have an effect on economic growth. The author argued that trade openness depends on the policy of individual countries and their geographical location. Hutchet et al. (2018) investigated the association between trade openness and economic growth in 169 countries by employing the Generalised Method of Moment. The results reveal that the country that exports more positively affects economic growth.

A majority of studies have focused on the effect of exchange rate on commodity prices and the impact of either exchange rate or commodity prices on economic growth. There are a few/no studies that put emphasis on all the four variables: commodity prices, trade openness, exchange rate and economic growth. Empirically, there is no study that has been conducted in South Africa that focuses on all these variables. Most importantly, no study has been conducted on the magnitude among commodity prices, exchange rate and economic growth in South Africa. Thus, this study investigates commodity prices, trade openness, exchange rate and economic growth in South Africa with the intention of understanding the effect of exchange rate and commodity prices on economic growth using the Vector Error Correction Model. Thus, the subsequent section discusses the research methodology used in this study.

\section{Methodology}

\subsection{Data Description}

The study used the quantitative approach in examining the effect of commodity prices, trade openness and real exchange rate on economic growth. The investigation was based on quarterly time series data from 1984Q1 to 2020Q4 sourced from the South African Reserve Bank (SARB) online facility. The data used includes economic growth, trade openness, real exchange rate and commodity prices. Economic growth was employed as a dependent variable, while trade openness, real exchange rate and commodity prices were used as independent variables. The nature of this relationship is shown in equation 1 :

$$
\mathrm{GDP}_{\mathrm{t}}=\beta_{0}+\beta_{1} \operatorname{lnRER}_{\mathrm{t}}+\beta_{2} \operatorname{lnCP_{\mathrm {t}}}+\beta_{3} \ln \mathrm{TO}_{\mathrm{t}}+\varepsilon_{\mathrm{t}}
$$

Where GDP is economic growth, lnRER is real exchange rate, $\operatorname{lnCP}$ is commodity prices and lnTO is trade openness. $\beta$ represents the coefficients of independent variables, $t$ represents time and $\varepsilon$ represents an error term. Table 1 gives more information on the variables used in the study.

Table 1. Variables used in the study

\begin{tabular}{|c|c|c|c|}
\hline Variable & Source & Description & Expectation \\
\hline $\begin{array}{l}\text { Economic } \\
\text { (GDP) }\end{array}$ & SARB & $\begin{array}{l}\text { An improvement in the quantity of goods and services } \\
\text { produced considering the population of South Africa }\end{array}$ & Dependent variable \\
\hline $\begin{array}{l}\text { Real exchange rate } \\
\text { (lnRER) }\end{array}$ & SARB & $\begin{array}{l}\text { Rand expressed over the US dollar minus prices and } \\
\text { wages. }\end{array}$ & $-/+$ \\
\hline Trade openness $(\operatorname{lnTO})$ & SARB & imports and exports expressed as a percentage of GDP & + \\
\hline $\begin{array}{l}\text { Commodity } \\
(\operatorname{lnCP})\end{array}$ & SARB & $\begin{array}{l}\text { Prices of raw materials and minerals that are traded in } \\
\text { the South African market }\end{array}$ & $+/-$ \\
\hline
\end{tabular}

Source: Authors compilation 


\subsection{Pre-estimation Techniques}

The estimation of results involves unit root tests, cointegration analysis and the lag length selection. The unit root tests were conducted to check the stationarity of variables under study and to ascertain the order of integration. To achieve these two aims, an Augmented Dickey Fuller (ADF) was employed. The tests prescribe that if the probability value is less than 10 percent, the variable becomes stationary. Garidzirai and Nguza-Mduba (2020) further explains that the unit root tests determine the methodology to use. The authors assert that if the variables are a combination of order zero and one, an ARDL is deemed fit, while VECM and VAR are appropriate when variables are stationary at order one (Pasara \& Garidzirai 2020). Furthermore, a Johansen cointegration analysis was employed to check if the long-run relationship exists between the variables under study. The cointegration analysis is composed the trace statistic and the maximum eigenvalue statistic (Garidzirai, 2019). These tests contain the use of along matrix $\prod$, that is a $k x k$ matrix rank $r$ (Gujurati 2015). In the event that the two tests come up with different results, the maximum eigenvalue test results would be preferred (Banerjee et al. 1993). Lastly, the lag order was determined using the Akaike Information Criterion (AIC).

\subsection{Estimation Technique}

Since the long-run association among commodity prices, trade openness, real exchange rate and economic growth was determined by the cointegration analysis, the Vector Error Correction Model analyses the short-run. It corrects all the disequilibrium's in the model. When analysing the short-run analysis, the coefficient and the p-value of the error term are important. The coefficient should be less than zero, negative and the p-value should be statistically significant at 1, 5 and 10 percent (Pasara and Garidzirai 2020). The VECM is specified in equation 2:

$$
\Delta Y_{t}=\beta_{1} \Delta X_{t}+\beta_{2}\left(y_{t}-1-Y X_{t}-1\right)+\varepsilon_{t}
$$

Where $\Delta Y$ stands for a dependent variable, $\Delta X_{t}$ stands for all the independent variables, $\beta$ stands for all the coefficients of independent variables and $y t-1-y x t-1$ represents a short term analysis. Equation 2 can be rearranged to fit all the variables under study. Thus, the actual VECM is shown in equation 3

$$
\begin{aligned}
\Delta G D P_{t}=\theta_{0} & +\sum_{i=1}^{q} \alpha_{j} \Delta G D P_{t-i}+\sum_{i=1}^{q} \beta_{1} \Delta \operatorname{lnRER} R_{t-i}+\sum_{i=1}^{q} \gamma_{2} \ln C P_{t-i}+\sum_{i=1}^{q} \beta_{3} \ln T O_{t-i}+\gamma_{4} E C M_{t-1} \\
& +\varepsilon_{t}
\end{aligned}
$$

Where $\alpha, \beta$ are the coefficients to be estimated, $\varepsilon$ is the error term, ECM is the Error Correction Term.

\section{Empirical Results and Discussion}

This section discusses the descriptive statistics, unit root tests, lag length, cointegration tests and Vector Error Correction Model results. The subsequent section discusses the descriptive statistics.

\subsection{Descriptive Statistics}

The descriptive results are illustrated in Table 2. The results show an average of 7.2 percent in commodity prices and 6.3 percent in real exchange rate. This means that commodity prices and the exchange rate are high in South Africa. An average economic growth of 2.1 percent was recorded which is slightly low compared to the targeted 5 percent (National Treasury 2020). The results further highlight positive coefficients in all the variables implying an upward direction throughout the time series. Furthermore, the variables are moderately skewed and normally distributed.

Table 2. Descriptive statistics

\begin{tabular}{lllll}
\hline Descriptive & GDP & InRER & $\operatorname{lnCP}$ & $\operatorname{lnTO}$ \\
\hline mean & 2.09192 & 6.32210 & 7.30128 & 3.02171 \\
\hline median & 2.14292 & 6.39510 & 6.91600 & 2.98288 \\
\hline maximum & 5.39121 & 9.67151 & 10.30261 & 5.30921 \\
\hline minimum & 0.29102 & 2.10381 & 3.10473 & 1.00291 \\
\hline Std.Dev & 1.02819 & 2.01891 & 2.52910 & 1.60926 \\
\hline Skewness & 0.92091 & 0.15931 & 0.63021 & 0.27613 \\
\hline Kurtosis & 3.29023 & 2.02322 & 3.41062 & 2.38091 \\
\hline Observation & 141 & 141 & 141 & 141 \\
\hline
\end{tabular}

Source: Own Compilation from Eviews software 


\subsection{Stationarity Test Results}

The study utilised the ADF in checking for stationarity and the results are outlined in Table 3 . The results show the probability values of more than 10 percent in all the variables under study. Thus, we conclude that the variables are not stationary at level. Since all the variables were found not stationary at levels, the researchers tested the variables at first difference and found all the p-values to be significant at 1 percent. This means that all the variables are stationary at levels and this justifies the use of the Vector Error Correction Model. Before estimating the VECM, the study used the Johansen cointegration test to check for long-run link among the variables. Thus, the Johansen cointegration test was discussed in the following section.

Table 3. ADF unit root test

\begin{tabular}{llllll}
\hline Variables & \multicolumn{2}{l}{ t-statistic and critical values } & Probabilities & & $\begin{array}{l}\text { Order } \\
\text { integration }\end{array}$ \\
\cline { 2 - 5 } & Levels & $\mathbf{1}^{\text {st }}$ Difference & Levels & $\mathbf{1}^{\text {st }}$ Difference & \\
\hline GDP & -1.209184 & -2.630182 & 0.3012 & $0.0000^{* * * *}$ & $\mathrm{I}(1)$ \\
& $(-2.193018)$ & $(-2.721937)$ & & & \\
\hline $\operatorname{lnRER}$ & -1.659588 & -2.205917 & 0.2043 & $0.0081^{* * *}$ & $\mathrm{I}(1)$ \\
& $(-2.381099)$ & $(-2.432617)$ & & & \\
\hline $\ln C P$ & -2.560800 & -7.098765 & 0.2099 & $0.0000^{* * * *}$ & $\mathrm{I}(1)$ \\
& $(-2.102938)$ & $(-2.174028)$ & & & \\
\hline $\ln$ TO & -2.281320 & -3.309173 & 0.3318 & $0.0000^{* * * *}$ & $1(1)$ \\
& $(-2.028129)$ & $(-2.391320)$ & & & \\
\hline
\end{tabular}

Source: Own compilation from Eviews software. Note: $* * *$ represents 1 percent significance level

\subsection{Johansen Cointegration Analysis}

Before employing the cointegration tests, a lag order selection was performed. The purpose of employing the tests was to choose the appropriate lag. The results of the lag length are illustrated in Table 4 and the lag 2 was chosen as the appropriate lag length. Thus, the model utilized lag 2 under the Akaike Information Criterion (AIC).

Table 4. Cointegration results

\begin{tabular}{lllllll}
\hline Lag & LogL & LR & FPE & AIC & SC & HQ \\
\hline 0 & -291.0281 & NA & 1.2052 & 7.2018 & 8.2017 & 7.8109 \\
\hline 1 & -129.2710 & 321.0182 & $4.12 \mathrm{e}-19$ & $3.2019^{*}$ & $3.2817^{*}$ & $1.9926^{*}$ \\
\hline 2 & -47.2871 & 70.2540 & $3.71 \mathrm{e}-31$ & 2.9165 & 4.0025 & 2.8730 \\
\hline 3 & 25.9219 & 69.8288 & $4.03 \mathrm{e}-47$ & 2.0029 & 5.7301 & 3.1092 \\
\hline
\end{tabular}

Source: Own compilation from Eviews software. Note: $*$ shows the significant lag

The Johansen cointegration results are reported in Table 5. Trace test results reveal that there are at least (3) cointegrating equations all levels of significance, thus, the rejection of null hypothesis. In the same light, the Maximum eigenvalue test also shows that there are (2) cointegrating equations at a 1 and 5 percent level of significance. The trace test and maximum test endorse a long run link among economic growth, commodity prices, trade openness and real exchange rate. Since the cointegration test has confirmed the existence of a long-run association among the variables, the next section discusses the long-run relationship. 
Table 5. Johansen Cointegration Test results

\begin{tabular}{|c|c|c|c|c|c|c|c|c|}
\hline \multicolumn{5}{|l|}{ Trace test } & \multicolumn{4}{|c|}{ Max Eigen value Test } \\
\hline None* & 0.6604 & 51.975 & 28.816 & $0.0001 * * *$ & 37.819 & 0.531 & 21.131 & $0.0004 * * *$ \\
\hline At most ${ }^{*}$ & 0.1433 & 4.9610 & 2.7655 & $0.0322 * *$ & 2.396 & 0.188 & 3.841 & $0.0342 * *$ \\
\hline
\end{tabular}

Source: Own Compilation from Eviews software. Note: ${ }^{*}, * * * * *$ represents 10,5 and 1 percent level of significance

\subsection{Long-Run Relationship}

The long-run association among economic growth, real exchange rate, trade openness and commodity prices is presented in Table 6. The results tell an expected and significant negative influence of real exchange rate (lnRER) on economic growth. Implicitly, the depreciation of the South African rand by one percent rises economic growth by 0.6341 percent. This therefore implies an increase in the price of imports, reduction of trading partner's exports, instinctively leading to a decrease in imports and an increase in exports. The increase in exports is achieved through the multiplier effect. The study's findings are in sync with other studies such as that of Khomo et al (2020) and Razzaque et al. (2017). The studies state that real exchange rate is a catalyst to economic growth in emerging countries such as South Africa. Likewise, the influence of commodity prices $(\operatorname{lnCP})$ was significant and positively influencing economic growth in South Africa. This means that a 1 percent increase in commodity prices leads to a 1.0110 percent increase in economic growth. This result was expected since South Africa relies on mineral and agricultural export commodities. Nyathi (2017) and Brixiova and Ncube (2014) concur with the results as they concluded that commodity prices play a crucial role in influencing economic growth. Lastly, trade openness (lnTO) was found to be significant and positively influencing economic growth. Therefore, a 1 percent increase in trade openness increases economic growth by 0.6240 percent. This result was expected since South Africa is a major trader with many countries. This result is in line with other studies such as Mizan (2019) and Hutchet et al. (2018).

Table 6. Long-run analysis

\begin{tabular}{lllll}
\hline Variable & Coefficient & Std.error & t-statistic & p-value \\
\hline $\ln R E R$ & -0.6341 & 2.4900 & -2.8429 & $0.0000^{* * *}$ \\
\hline $\ln C P$ & 1.0110 & 3.3891 & 3.6790 & $0.0008^{* * *}$ \\
\hline $\ln \mathrm{TO}$ & 0.6240 & 2.5091 & 3.1289 & $0.0018^{* * *}$ \\
\hline Constant & 3.4092 & 4.7024 & 5.8916 & $0.0000^{* * *}$ \\
\hline
\end{tabular}

Source: Authors compilation from Eviews software. Note: *** represents 1 percent.

\subsection{Error Correction Model}

Since a long-run relationship has been established, a short-run association of the variables is analysed using the VECM and the results are shown in Table 7. The results reveal that trade openness was significant in explaining economic growth, while commodity prices $(\operatorname{lnCP})$, exchange rate (lnRER) were not significant in explaining economic growth in the short-run. The results further reveal an ECT of -0.50391 that is significant at 1 percent. The ECT has an expected negative coefficient sign confirming that the current disequilibrium can be corrected in the long-run. Thus, the 54 percent in the disequilibrium of commodity prices, real exchange rate and trade openness can be corrected in 1 year 9 months (1/0.50391) to achieve the desirable economic growth. 
Table 7. Short-run analysis

\begin{tabular}{lllll}
\hline Variable & Coefficient & Std.error & t-statistic & p-value \\
\hline $\ln R E R$ & -0.2937 & 2.4810 & -2.9029 & $0.0000^{* * *}$ \\
\hline $\ln C P$ & 0.0451 & 3.3891 & 3.6790 & $0.0000^{* * *}$ \\
\hline $\ln T O$ & 0.3491 & 2.5091 & 3.1289 & $0.0049 * * *$ \\
\hline ECT & -0.50391 & 6.1005 & 6.2341 & $0.0000^{* * *}$ \\
\hline
\end{tabular}

Source: Authors compilation from Eviews software. Note: *** represents 1 percent.

\subsection{Granger Causality Analysis}

The Pairwise Granger causality analysis was employed and the results are presented in Table 8 . The findings of the study show that commodity prices and real exchange rate granger cause economic growth. Furthermore, the results show a bidirectional between trade openness and economic growth. The Granger causality results confirms the long-run relationship.

Table 8. Granger Causality Test results

\begin{tabular}{llll}
\hline Null hypothesis: & Obs & F-Statistic & Prob. \\
\hline GDP does not Granger Cause lnCP & 30 & 0.65497 & 0.5281 \\
\hline lnCP does not Granger Cause GDP & & 0.79191 & $0.0420^{* *}$ \\
\hline GDP does not Granger Cause LRER & 30 & 0.36485 & 0.6979 \\
\hline LRER does not Granger Cause LRGDP & & 0.67026 & $0.0576^{*}$ \\
\hline GDP does not Granger Cause lnTO & 30 & 0.62124 & $0.0000^{* * *}$ \\
\hline lnTO does not Granger Cause GDP & & 1.14650 & $0.0073^{* * *}$
\end{tabular}

Source: Authors compilation from Eviews software. Note: *, **, *** represents 10, 5 and 1 percent level of significance respectively.

\subsection{Post-Estimation Analysis}

Table 9 presents the diagnostic test results. The Jarque-Bera (0.481307) normality test showed that residuals are normally distributed and the p-value does not lead to the rejection of the null hypothesis. On the other hand, the diagnostic tests in Table 9 show no evidence of heteroscedasticity, since the p value is greater at a 5 percent level of significance level. The presence of heteroscedasticity meant that the model has some misspecification, hence conclusive results cannot be derived from such a model.

Table 9. Diagnostic results

\begin{tabular}{llll}
\hline Test & Test Statistic & p- value & Conclusion \\
\hline $\begin{array}{l}\text { Normality Test } \\
\text { (JB test) }\end{array}$ & 1.4625 & 0.48137 & $\begin{array}{l}\text { Do not reject Ho since PV> L.O.S residuals are } \\
\text { normally distributed }\end{array}$ \\
\hline $\begin{array}{l}\text { Autocorrelation } \\
\text { (Order 6) }\end{array}$ & 24.6452 & 0.7300 & $\begin{array}{l}\text { Reject Ho since PV }<\text { L.OS. there is no } \\
\text { autocorrelation in the model }\end{array}$ \\
\hline $\begin{array}{l}\text { Serial Correlation } \\
\text { (LM test) }\end{array}$ & 15.3750 & 0.1625 & $\begin{array}{l}\text { Reject Ho since PV }<\text { L.O.S, No evidence of } \\
\text { serial } \\
\text { correlation }\end{array}$ \\
\hline $\begin{array}{l}\text { Heteroscedasticity } \\
\text { test (white test) }\end{array}$ & 5.4389 & 0.3647 & $\begin{array}{l}\text { Do not reject Ho since PV> L.O.S. no evidence } \\
\text { of heteroscedasticity }\end{array}$ \\
\hline
\end{tabular}

Source: Author 


\section{Conclusions and Recommendations}

The purpose of this study was to investigate the effects of commodity prices, exchange rate and trade openness on economic growth in South Africa. The study provided more insight on how these variables influenced economic growth from 1984-2019. The results reveal that commodity prices and trade openness increase economic growth in South Africa, holding other things constant. On the other hand, a decrease in the real exchange rate leads to an increase in the economic growth. The aforementioned variables are the key catalysts to economic growth and globalization. Given that South Africa is an emerging country, these findings are in sync with the economic theory and the literature herein. Based on the study`s results, the researchers recommend a devaluation of the currency to promote exports, employment, production and economic growth. The devaluation of the currency serves as a triple action to macroeconomic objectives as it solves unemployment, poverty and economic growth. Furthermore, the commodity prices should be kept in check to avoid commodity instability that is hazardous to economic growth. Although, the study has achieved its objective, two limitations were identified. Firstly, the study should have added more variables such as financial development. Secondly, the study should have included many cross-sections. However, these limitations will be addressed in the upcoming studies.

\section{References}

Acarm. (2000). Devaluation in developing countries. Expansionary or contractionary. Journal of Economic and Social Research, 2(1), 1-17.

Banerjee, A., Dolado, J., Galbraith, J., \& Hendry, D. (1993). Co-Integration, Error Correction, and the Econometric Analysis of Non-Stationary Data. https://doi.org/10.1093/0198288107.001.0001

Brixiov, Z., \& Mthuli, N. (2014). The Real Exchange Rate and Growth in Zimbabwe: Does the Currency Regime Matter?. William Davidson Institute Working Papers Series wp1081, William Davidson Institute at the University of Michigan. https://doi.org/10.2139/ssrn.2507938

Cavalcanti, T. (2011). Commodity prices and exchange rate in South Africa. Retrieved June 20, 2020, from http//www.IMF.Org/external/pubs/FP/WP/2012/WP12/2.Pdf

Dao, A. T. (2014). Trade Openness and Economic Growth. Mark A. Israel '91 Endowed Summer Research Fund in Economics, 2.

Djordjevic, B. S. (2019). Commodity prices and economic growth: an empirical study from Serbia. Economic and Social Development: Book of Proceedings, pp. 44-55, Varazdin Development and Entrepreneurship Agency (VADEA).

Ehigiamusoe, K., \& Lean, H. H. (2019). Do economic and financial integration stimulate economic growth? A critical survey. Economics: The Open-Access, Open-Assessment E-Journal, 13. hptts://doi.org/10.5018/economics-ejournal.ja.2019-4

Garidzirai, R., \& Nguza-Mduba, B. (2019). Does tourism contribute to local economic development (LED) in the City of Cape Town Municipality? A time series analysis. African Journal of Hospitality, Tourism and Leisure, 9(1), 1-13.

Garidzirai, R. (2019). An Economic Analysis of Local Economic Development and Exports: A Case Study of the Rand West Local Municipality. Journal of Public Administration, 54(4.1), 729-738.

Gries, T., \& Redlin, M. (2012). Trade Openness and Economic Growth: A Panel Causality Analysis. Working Papers CIE 52, Paderborn University, CIE Center for International Economics.

Gujarati, D. (2015). Essentials of Econometrics (4th ed.). New York: McGraw-Hill. https://doi.org/10.1007/978-1-137-37502-5

Huchet, M., Mouel, C. L., \& Vijil, M. (2018). The relationship between trade openness and economic growth: Some new insights on the openness measurement issue. The World Economy, 41(1), 59-76. https://doi.org/10.1111/twec.12586

Jawaid, S. T. (2014). Trade Openness and Economic Growth: A Lesson from Pakistan. Foreign Trade Review, 49(2), 193-212. https://doi.org/10.1177/0015732514525223

Keho, Y. (2017). The impact of trade openness on economic growth: The case of Cote d'Ivoire. Cogent Economics \& Finance, 5(1), 1-18. https://doi.org/10.1080/23322039.2017.1332820 
Malefane, M. R., \& Odhiambo, N. M. (2018). Impact of trade openness on economic growth: Empirical evidence from South Africa . Working Papers 23654, University of South Africa, Department of Economics. https://doi.org/10.1177/0972150919830812

Miyajima, K. (2019). Exchange Rate Volatility and Pass-Through to Inflation in South Africa. IMF Working Papers 19/277, International Monetary Fund. https://doi.org/10.5089/9781513521572.001

Mizan, A. (2019). Trade Openness and Economic Growth: A Panel Data Analysis on Developing Countries from 1998-2017. Masters thesis, Rhine-waal University.

Mputu, C. L. (2016). Terms of Trade, Trade Openness and Economic Growth in Sub-Saharan Africa. Culminating Projects in Economics, 3.

Muzekenyi, M., Zuwarimwe, J., Kilonzo, B. M., \& Nheta, D. S. (2019). An Assessment of the Role of Real Exchange Rate on Economic Growth in South Africa. Journal of Contemporary Management, 16(2), 1-20. https://doi.org/10.35683/jcm18067.0008

Muzhani, M. (2018). Fixed or Flexible Exchange Rates? History and Perspectives. Vernon Press Titles in Economics 250(1).

National Treasury. 2020. Budget Review. Retrieved July 1, 2020, from http://www.treasury.gov.za/documents/National\%20Budget/2020/review/FullBR.pdf

Ofori-abebrese, J., Pickson, R. B., \& Ofori-abebrese, G. (2017). Commodity prices, exchange rate and economic growth in West Africa: Case study of Cote d'Ivoire and Ghana. Journal of Development and Agricultural Economics, 9(9), 269-277.

Ojuolape, A., Yusuf, H., \& Alabi, M. O. (2015). The effects of currency devaluation on output growth in developing economies with currency crises. International Journal of Economic Research, 12(4), 1143-1157.

Pasara, M. T., \& Garidzirai, R. (2020). The Boomerang Effects: An Analysis of the Pre and Post Dollarisation Era in Zimbabwe. Economies, 8(2), 1-20. https://doi.org/10.3390/economies8020032

Razzaque, M. A., Bidisha, S. H., \& Khondker, B. H. (2017). Exchange Rate and Economic Growth: An Empirical Assessment for Bangladesh. Journal of South Asian Development, 12(1), 42-64. https://doi.org/10.1177/0973174117702712

Rodrik, D. (2008). The real exchange rate and economic growth. Brookings Papers on Economic Activity, 365-412. https://doi.org/10.1353/eca.0.0020

Schaling, E., Ndlovu, X., \& Alagidede, P. (2014). Modelling the rand and commodity prices: A Granger Causality and Cointegration analysis. South African Journal of Economic and Management Science, 17(5), 22-36. https://doi.org/10.4102/sajems.v17i5.334

Vieira, F. V., Holland, M., Gomes, D. A., Silva, C., \& Bottecchia, L. C. (2013). Growth and exchange rate volatility: a panel data analysis. Applied Economics, 45(2), 3733-3741. https://doi.org/10.1080/00036846.2012.730135

Zhanje, S., \& Garidzirai, R. (2018). Export Performance and Foreign Direct Investment in Zimbabwe: An ARDL Approach. International Conference on Public Administration and Development Alternatives, 04 - 06 July 2018, Stellenbosch University, Saldahna Bay, South Africa.

\section{Copyrights}

Copyright for this article is retained by the author(s), with first publication rights granted to the journal.

This is an open-access article distributed under the terms and conditions of the Creative Commons Attribution license (http://creativecommons.org/licenses/by/4.0/). 